\title{
AXP AutoXpress Platform
}

National Cancer Institute

\section{Source}

National Cancer Institute. AXP AutoXpress Platform. NCI Thesaurus. Code C95519.

A proprietary system for recovery of stem-cell rich fractions from human umbilical cord blood and volume reduction of blood components. 